\title{
1
}

\section{Securitisation, development and the invisibility of gender}

\author{
Stephanie Lusby \\ The Australian National University
}

\section{Introduction}

Discussions of violence are ubiquitous in, and with regard to, Papua New Guinea. In this chapter, I discuss how persistent broader contexts of legitimised violence shape efforts to destabilise particular patterns of violence, namely, male violence against women. Looking at the perspectives of men working in the security industry in PNG, I argue that the increased traction and centrality of discourses of securitisation in the name of national development allows violence against men accused of criminal or anti-social behaviour to persist. Critically, the silences around the gendered dimensions of violence between men excused as 'disciplinary' produces double standards that are unhelpful to efforts to improve gender equality. Here, I seek to illustrate that narratives of discipline and security form a continuum in discussions of violence, highlighting the need for politicised and holistic approaches to gender in violence interventions.

Violence frames development policy in significant ways. It directly impacts on the quality of life of victims of crime and those who fear being victims (Goldstein 2010; Lakhani and Willman 2014). Within contemporary discourses of development, public violence is further represented as a threat to foreign investment, economic growth and the country's future, 
as well as the stability and growth of the region (Dinnen and Mcleod 2008; Lakhani and Willman 2014; Scott 2005). Within these framings, which are predicated on notions of state security, the bolstering of the capacity of law and order agencies to respond to crime is of primary concern. Immediate responses either by state agents or by private security firms acting alongside or even in proxy for police often involve violence being made legitimate through its purpose of improving security and therefore community well-being.

Responses to violence against women, particularly private violence that occurs in homes and by people otherwise known to the victim, is framed in slightly different ways. Although improving police and court responses are critical here too, public awareness campaigns focus more on shifting social norms that deny women's rights to bodily autonomy, safety, and equal access to justice. Broadly speaking, within frameworks of securitisation, punishment and disciplinary action are foregrounded with the aim of deterring others from enacting violent crime. Rights-based approaches have a different emphasis, giving greater attention to prevention strategies aimed at changing men's behaviour and encouraging broader attitudinal change with regard to the rights and roles of men and women. Whether talking about public or private violence, however, men are more likely to be the perpetrators of violence, whether as street criminals, referred to as raskols, as security agents, or as domestic assailants. Men are the key targets, then, of both approaches to crime response and prevention.

Programs built along each strategy are designed to work in concert and complementarity: adequate law enforcement responses to family and sexual violence, for example, are critical to precipitating behaviour change (CIMC and FSVAC n.d.; Klugman et al. 2014; Merry 2006). However, while the gendered dimensions of violence against women by men are central to those discussions, they are almost invisible in mainstream discussions of securitisation. Violence between men as raskols, and predominately men as security and police, is just violence; the gendered contours of those interactions are rarely scrutinised.

In this chapter, I endeavour to unpack the gendered character of violence between men, and how the logic applied to expressions of aggression done in the name of discipline and security intersects with anti-violence against women initiatives. How do men narrate violence against men that is done in the name of social control? And what does that mean for how they narrate violence against women? I argue that the gendered meanings 
of violence committed as a result of criminal or anti-social activity, and excessive force against citizens used in the name of social order and security is ostensibly the same; that both are articulations of aggressive masculinity. As Sally Engle Merry reminds us, 'While violence exists in a culture-free zone of injury and death, it's meanings are deeply informed by social contexts' (Merry 2006: 24). These meanings allow violence to be interpreted as either legitimate or illegitimate. Thus the broad acceptance of disciplinary violence between men in the name of 'security' undermines attempts to destabilise excuses for male violence against women that rest upon sexist logic of women's need to be disciplined by men, and their morals and bodies policed.

I explore these issues through considering the perspectives of entrylevel security guards in Kokopo, East New Britain. Over a three-month period in 2012, I conducted weekly discussion groups with between 10 and 30 men working as guards. Their perspectives are critical to understanding how different development discourses about violence and its legitimacy are hybridised and gendered. This is because of what the security industry represents within the political economy of Papua New Guinea's development, and what they can tell us about how this affects the personhood of young men engaged in security work.

\section{Violence and the security industry}

The security industry is hugely important in Papua New Guinea. Concerns about safety, crime and the capacity of law and order agencies to respond are not novel in PNG. However, in the almost two decades since securitisation for development became a dominant narrative globally, and for PNG and its donor partners (Goldstein 2010; O'Connor, Chan and Goodman 2006; Scott 2005), security companies have been relied upon increasingly to fill lacunae in state capacity (Dinnen 2001; Lakhani and Willman 2014; SIA 2014). In 2006, there were 173 firms registered with the SIA (Security Industries Association, after 2014 Security Industries Authority). As of December 2013, there were 470 registered companies and 24,000 guards, and more suspected of operating unregistered (limited staff capacity within SIA prohibits accurate monitoring of all companies across the country) (private discussion with Paul Kingston Asari, 28 August 2014). 
On their website, the SIA theorises about the growth of the security industry, writing that it is partly due to the insufficient manpower in the law enforcement agencies to meet the basic security needs of the 7 million PNG citizens. Consequently licensed private security companies are taking advantages of this to fill the vacuum to perform quasi law enforcement duties' (SIA 2014). A recent World Bank survey of the social and economic costs of violence in PNG found that many business houses 'acknowledged that they hired private security to help secure their premises, but also often turned to private security in lieu of the police in the event of an incident' (Lakhani and Willman 2014: 9). However, security guards are not hired for the protection of the community at large, but are for-profit companies designed to protect the particular interests of those who engage their services and whose business growth depends on a continuing sense of insecurity from those who can afford to pay for security services. In the same World Bank study, some respondents reported suspicions that:

private security companies may also create 'security incidents' by staging an attack on a business premises. This, allegedly, is done in order to create demand for their services or to undermine their competitors (Lakhani and Willman 2014: 10).

The rise in security has coincided with a depreciation of confidence in state policing. In 2012, there were 184 police stations across PNG, including posts of only one or two officers, and 5,387 uniformed officers, only 623 of whom were women (Papua New Guinea-Australia Law and Justice Partnership 2013). Many Papua New Guineans have an ambivalent relationship with police, with accusations that the law 'lacks teeth'- that is, does not pose adequate risk of punishment to criminals so as to deter crime, and excessive use of force and police brutality are both commonly reported complaints (Akmeemana et al. 2014; Human Rights Watch 2005). With regard to the former, limited staff numbers impinge on responses to call outs. This is compounded with poor investigative capacity at many stations, which, in turn, impacts on whether complaints will progress to arrest or court hearings (Dinnen 2001). 'Emergency responses' to suspected 'gang' or raskol crime by police often involve brutal raids on settlement areas accused of harbouring criminals. Police violence-during raids, arrests and when detainees are incarcerated in police stations_-is reportedly common (Human Rights Watch 2015). 
Although not unproblematised, there are also widely held public perceptions that 'something must be done' to address crime in PNG, and there is a political onus to be tough on crime. Despite some observers noting that, rather than resolving issues of criminal violence, police raids in Port Moresby, for example, in fact seem to exacerbate problems (Dinnen 2001), tacit acceptance of some degree of police violence is widely prevalent in media and public discourse across the country. Grudgingly permissive attitudes towards institutional violence are reinforced by narratives of securitisation and public fear, but also validate the notoriously macho cultures within the Royal Papua New Guinea Constabulary (RPNGC). Despite institutional efforts to elicit change through gender sensitivity and operational training (Macintyre 2012; Mcleod and Macintyre 2010), such attitudes remain pervasive and continue to perpetuate aggressive masculinity within the force, resulting in human rights abuses against men, women and children accused of committing or being complicit in crimes (Amnesty International 2006; Human Rights Watch 2005, 2015).

These same philosophies and practices have translated into the operations of security personnel. However, as 'quasi-law enforcement', security guards are not privy to the same levels of training, public scrutiny or regulation as state services. Even though such checks and balances are often shown to be inadequate, and change is slow within the police force, protocols still exist and fall under the purview of government and donor analysis. There is no standardised training curriculum or institution in Papua New Guinea for security guards. The SIA dedicates a section on their website appealing to industry members to help to establish a private college, noting that such an institution is a requirement under the Security Protection Act (Independent State of Papua New Guinea 2004). The website notes that because guards currently receive only ad-hoc training, all the security guards currently employed in the industry are either not trained or insufficiently trained'. The site goes on to say that:

the establishment of a private security academy is very important to our long term interest to urgently up skill, rehabilitate and empower the security guards so they are controlled and well disciplined to provide quality services to the services receivers. By doing this all bad habits and serious allegations will be reduced and the integrity of the industry will be maintained (SIA 2014).

The 'bad habits and serious allegations' are indeed cause for concern. There have been several high-profile cases of crimes committed by security guards in PNG that have recently received international attention. Barrick 
Gold paid compensation in an out-of-court settlement to 11 of 200 women raped by security personnel hired by the company at Porgera Mine (McVeigh 2015). Australian and Papua New Guinean security guards at the Australian-controlled Manus Island Processing Facility were found to be culpable for violent assaults on asylum seekers in February 2014 (Davey 2014). Australian and Papua New Guinean security guards at the Manus Island facility were found to be unregistered with the SIA at the time of the 2014 riots, where security guards were found responsible for the death of asylum seeker Reza Berati (Wolfe 2014). ${ }^{1}$ Other stories of everyday assaults by guards against citizens are occasionally reported in local news media, and regularly appear on social media sites. The World Bank study found that, although use of firearms by security personnel is restricted under the Security Protection Act, police weapons were found to be in use by some guards (Lakhani and Willman 2014: 10). Poor regulatory capacity of the SIA means that addressing assaults or misconduct committed by security personnel relies on internal disciplinary measures, or victims being able to report crimes to police and having police respond. As a result, the macho posturing and violence that is enacted by police under the guise of social protection is also perpetuated throughout the security industry, arguably in less visible and more pervasive ways.

Daniel Goldstein observes that the meaning of 'security' is entirely reliant on that which is defined as a threat (2010). The line between categories in Papua New Guinea is slippery and subjective, as responses to anti-social threats in the form of criminal or alleged criminal activity from security forces can be as much a source of uncertainty and fear for communities as the behaviour of raskols. Nonetheless, the pervasive fear of violence generally, and its anticipated ill-effects on economic development in particular, means that despite its issues, security remains a growth industry. Consequently, in the small formal employment market in

1 The Manus Island Processing Centre has been a contentious issue within PNG, as well as in Australia, since reopening in 2012. The encounters between local youths and notorious PNG Mobile Squad officers, brought in as additional security to Manus Island when the centre reopened, resulted in at least one death (Callinan 2013). There have been ongoing allegations of unequal treatment of local and ex-patriot security guards, with local guards receiving limited training, and reporting poor working conditions. Elected representatives of Manus Island have repeatedly stated that the promised benefits to Manus Islanders, in terms of jobs and inputs into local economies, have not materialised and have been outweighed by negative impacts from the processing centre. The Supreme Court of Papua New Guinea ruled that the Manus facility was unconstitutional in April 2016 (Anderson 2016). At the time of writing, conditions of the closure have not been finalised. 
PNG (Pacific Economic Monitor 2014), it is also a significant employer, especially of young men. In the next section, I consider who the guards are and how they discuss threats and acts of security in their own experiences.

\section{Raskols and concerned citizens}

\section{How would you translate 'violent man' to Tok Pisin?}

Man bilong pait, man nogut—em tok nogut, bikhet man [a fighter, a nogood man - he swears and insults people, he's a big head] ... no discipline.

Group discussion with Kokopo Security Guards, 19 September 2012

The composition of the security industry in PNG is diverse. On the one hand, there are the large multinational corporations such as G4S and Transfield Services employing or contracting salaried, trained and armed guards to protect their clients' people and assets. On the other, there are the under-trained and poorly paid guards—sometimes working for the same companies, or for smaller, local firms-who are a common and conspicuous presence in urban areas and resource enclaves. The guards who participated in this research were employed by a locally owned company, whose operations were based mostly in East New Britain as well as contracting out to other parts of the country. Most of the regular guards (as opposed to operations and staff managers) were paid around minimum wage, which at the time of the research was K2.20 (US\$0.45) per hour. They worked one week on, during which time they stayed at the company barracks in Kokopo Town, and then had a week off where they were able to go back to their home villages. The company owner described this as a deliberate policy to allow staff to tend to their family and community commitments, but some guards said that working parttime made it difficult to earn enough money to support themselves.

Most of the guards were Tolai from East New Britain, with a small number of men who identified as indigenous minorities from other parts of the province. Some men were migrants from neighbouring West New Britain, New Ireland and mainland provinces. Others were part of the Sepik and Highlands diaspora whose families had settled in East New Britain decades before, or were of mixed Papua New Guinean ethnicity. Although many of the Tolai guards demonstrated generally discriminatory attitudes against waira, strangers, this was not outwardly directed against 
their work mates with whom they had a shared identity as members of the company. The majority of guards were men who had left school at Grade 8 or earlier, usually because of problems with finding the school fees necessary to continue. Many had poor literacy skills and struggled to engage paid work outside of the security sector. They had some access to land but found it difficult to make a living from it, and complained of land shortages catalysing conflicts, which made face-to-face violence and use of poisin or sorcery a problem (Mitchell 2000: 199; for a discussion of sorcery and urban violence in Vanuatu, see Banks 1993: 107-109; Eves 2013). Some of the guards had been disenfranchised from land and communities as a result of past poor behaviour, which distanced them from their families, although some of these relationships were said to be possible to redeem. Others said that they had had limited access to customary fraternities, either because as migrants they were away from their clan or ethnic groups or, for locals, because they did not have enough family resources or connections to sponsor initiation into the Dukduk Society (gatherings of the Tolai secret men's society) (Banks 1993). The guards said that children who had been adopted, who were of mixed ethnic parentage, or had divorced parents were more likely to be excluded from initiation.

The company deliberately fostered a pseudo-military workplace environment, with attendant prioritisation of discipline and loyalty. Guards were punished in approximations of codes used in military units or, at least, military units as portrayed in popular action films and television shows (Macintyre 2008; Mitchell 2000). During their working week, guards were expected to salute on the approach of the company owner, either on foot or as his car passed, leaping to their feet, hands clasped at chest height and loudly saying, 'Boss!' Failure to do so resulted in having to drop where they stood and, in the familiar stand-by of Hollywood army movies, do a number of push-ups. Less innocuous forms of discipline were also used. Although the guards were only supposed to work eighthour shifts, often, they said, their relieving shift would not turn up. But if they left their post before someone else changed with them, or fell asleep while on duty and were caught, this might be cause for a beating from superior officers. Although the guards reported dissatisfaction with many aspects of their work, including the threat of violence from members of the public while on duty, I have no record of them complaining about being physically 'disciplined' in the workplace. 
Indeed, the guards talked about using similar kinds of force to keep community peace, particularly in mixed ethnic communities where 'people have got different ways of thinking, different ideology' (Group discussion with Kokopo Security Guards, 12 September 2012). As Lars Buur observes, where violence is disciplinary it is nearly always directed at the future in the form of "prevention", "change of behaviour", and "learning the right way" (2008: 577). One man gave an example of a youth from East Sepik who was branded a ring-leader regarding trouble in the community.

He's a bikhet boy, bikhet stret. Like, he drinks a lot and he influences others to be like him; when he goes to Rabaul he goes around with street boys and they all cause trouble. The thing is, when he drinks, he swears. Swears inside the community, tok nogut inside the community. He has no respect for the bigman or the elders inside the community. People hate him for it, for his attitude ... But the thing is, whatever you do, you have to face the consequences. So one time, this boy went back home and everyone beat him up. It was big, he was even cut with a knife and got admitted to the haus sik. When he came out of the hospital, he'd changed. He was a good boy again (group discussion with Kokopo Security Guards, 19 September 2012).

In this example, the violence used was narrated as having been redemptive and helpful, both for the individual being 'taught a lesson' and the community who gained a reformed citizen.

The guards talked a lot about being 'caught between' the village and town, kastom and state laws, saying, 'Ol konfus i stap. Wanen we lo behind?' (Everyone is confused. Which direction should we follow?) Where are we? Where do we belong?' (group discussion with Kokopo Security Guards 19 September 2012). They felt that they imperfectly straddled ways of supporting themselves and their families, being on the periphery of land access, social support and waged labour (Munro, this volume).

These same dynamics of precarious livelihoods and uncertain social statuses that the guards said they felt also appear often in explanations of contemporary violence and crime in Papua New Guinea. Sinclair Dinnen writes:

The relationship between the security industry and raskolism is essentially symbiotic. Even though private security feeds off high levels of crime and insecurity, criminals looking for legitimate openings have shown consistent preference for employment in the security business ... 
The practical skills of raskolism, associated with the masculine attributes of toughness and physical prowess, are seen as consistent with those required by security guards. These positions also require few formal qualifications (2001: 97).

At various points in their lives, men might drift in and out of practicing raskolism and being part of a mob of 'concerned citizens'; identifying on the one hand as deserving or easy targets of theft or violence, and on the other as bikhets in need of discipline. Christine Stewart also identifies that police, security guards and raskols exist on a:

continuum ... [sharing] class origins and ideals of masculine comportment and consumption ... both groups feel betrayed by a state which fails to provide employment for the unemployed (the raskols) or decent living and working conditions for those it does employ (the police) (2014: 53).

Violence as an expression of masculinity and as an expression of frustration at the disappointments attendant to late capitalism for many in PNG are shared across different articulations of precarious livelihoods, particularly in urban settings and resource enclaves.

There are few spaces where the boundary between security enforcer and potential raskol is more porous than within the security industry itself. Security represents one of the few formal employment opportunities for men with limited qualifications, and access to (and sometimes interest in) agricultural livelihoods (Dinnen 2001). Certainly not every guard has been involved in crime, or vice versa, but many belong to the same demographic of disenfranchised—and disenchanted—young men.

Although crime and violence are threats to wellbeing and condemned by women and men who are potential victims, there is, at the same time, a certain empathy for raskols and 'big head' youths in communities. In workshops exploring community perceptions of crime in Lae, a city badly affected by violent crime, Martha Macintyre found that:

the word 'frustration' (used by Tok Pisin as well as English speakers) was used to describe the emotion that women believed inspired men and adolescent boys to smoke marijuana, drink alcohol and behave violently. This term recurred in workshops with police and was invoked to both explain and excuse illegal violence (2008: 182).

Reinforcing the arguments made here, women participating in the workshops stated that as well as beer, guns and marijuana, raskols and police all needed to be got rid of in order to make communities safe, 
with one participant saying, 'who can tell the difference?' (ibid.). Similarly, Dinnen found that 'much of the discussion of raskol crime moves between its essentially passive depiction as a symptom of deepening inequalities, and its significance as a form of political dissent' (2001: 47).

Anti-social behaviour thus takes on meaning as a social stand against feelings of disempowerment and those said to have caused it: government, 'elites', and 'all the people who don't take notice of them' (Macintyre 2008: 182). Dinnen writes:

Many raskols do try to legitimate their activities by reference to government failure to deliver essential services, lack of economic opportunities, social injustice, and growing levels of corruption among the national elite. These views also underlie the ambivalence in popular perceptions of raskolism in many parts of the country (2001: 47-48).

Community understanding, however, has its limits. Young men who turn to crime are not, after all, the only ones who must work to navigate precarity and its attendant disappointment and frustration. By reacting with righteous aggression, they add to the difficulties of others in their communities combating the same political economies that impede livelihoods and access to basic services. Keir Martin observes that around Rabaul, East New Britain, 'many Tolai are aware of the economic changes that have led to this state of affairs and therefore have some sympathy with the plight of these young men' (2013: 149). At the same time, the youths are regarded with frustration and embarrassment, their own alleged laziness and poor attitudes placed at fault, meaning that 'most of the time they are cast as the problems themselves' (ibid.: 150).

Macintyre shows how the aggressive masculinity that results in illegal violence is 'simultaneously sociable-for it aims to gain the admiration of other men-and anti-social, in that it is often harmful, illegal and disruptive of social harmony' (2008: 180). Despite the inaccurate connotations of the term 'gangs' when applied to crime in Papua New Guinea, ${ }^{2}$ criminal activity is nonetheless distinctly social. It is undertaken as much for prestige and to attain membership of a group in the face of being part of 'a whole generation that the new economy seems to have

2 The word 'gang' is used here to describe groups of peers, some of whom engage in criminal activity, but others who do not (Dinnen 2001). The term has a quite different meaning than when associated with gang activity in other parts of the world. Loyalty and affiliation is less fixed, and membership far more mobile than, for example, might be normal for gangs in cities and prisons of the US or South Africa. 
cast as being surplus to requirements' (Martin 2013: 152), as for material gain or to vent 'frustration'. The comportment of young men-from their clothes, to their hairstyle, consumption of music and even the ways that they pose in photos, throwing up hand signs borrowed from globalised hip hop and dancehall 'gangsta' style (Alim 2009)—speaks to a Melanesian version of what Macintyre refers to as 'youth polyculture' (2008: 183).

The ways in which men seek to move beyond social acceptance within a peer group, and try to gain respectability and the social acceptance of the whole by proving themselves to be good citizens is, as I have argued, multidirectional. As Joseph, a former security guard, put it to me when discussing his future hopes, he wants 'to be a good human resource for my country' (Interview with Joseph, Kokopo, 16 April 2012). This clearly also highlights the neoliberal contours of such ambitions. Acting as a security guard is a way to apply learned ways of gaining social power as a male through violence, towards new frameworks of personhood; aggressive masculinity for good rather than for ill. Securitisation narratives allow violence to be constructed as punitive rather than retributive, disciplinary instead of vindictive, and therefore as contributing to modern development futures (Buur 2008). In the remainder of this chapter, I turn to a discussion of the different ways this logic was made malleable and utilised in narratives of 'disciplinary' violence by men against women.

\section{Violent meri}

Interviewer: What about 'violent woman' in English, how would you say that?

Guard: Meri bilong pait, bilong kiross, bilong tingting nogut, bilong spak (Women who fight, who have bad tempers, are suspicious, get drunk) dance at different clubs all the time, go here and there, pait bilong man [fight over men] (group discussion with Kokopo Security Guards, 19 September 2012).

The guards insisted that the laws that forbade violence against women were well-known and publicised through community announcements, radio, poster and television campaigns. While still in training, the guards were required to attend workshop sessions about HIV, which included talking about violence in relationships and 'gender roles and responsibilities' (Wardlow 2011). The owner of the company was a vocal supporter of the national and provincial HIV response, and publicly declared his desire to improve the wellbeing, safety and access to rights for local women. 
Indeed, Sammy, one of the operations managers I had worked closely with had been fired at the beginning of 2013 because, I was told, the boss had heard that Sammy beat his wife.

The decision of the security firm to fire Sammy because of reports of wife beating was, I thought, laudable. To the best of my knowledge, the first employer in the Province to enforce a similar policy had been PNG Ports, a major sponsor of White Ribbon Day, for whom this was a national policy (PNG Ports Corporation 2013). Making domestic assault a sackable offence made a powerful public statement about the unacceptability of violence against women. And yet, there was incongruity in the fact that the company would damn an act of violence committed by a male staff member against women, when I knew that in normal operations-and in communities-violence was an acceptable means of instilling 'discipline' in men.

In the discussion groups with the guards, it became apparent that there were two ways that this apparent contradiction was reconciled (though these were not mutually exclusive). First, women were talked about as weak, fragile and unable to withstand the kinds of punishment that men could. One guard told me, 'Meri olsem skin bilong em i no strong. Mipla man olsem, skin bilong mipla em strong' (Women's skin is weak. Us men, our skin is tough) (Group discussion with Kokopo Security Guards, 19 September 2012). Relatedly, hitting women in a household was talked about as a risk to the smooth running of the house.

'Nogut yu paitim meri na meri dai lusim yu' (No good you hit your wife and then she dies and leaves you). Who'll look after the kids? Like, if we were married and I beat you up and broke your ribs, I won't have a woman to cook for me, I'll have to do all the work because you're dead or your hand is broken and so it's hard to wash clothes, things like that (discussion with Silas, North Coast Rabaul, 20 October 2012).

Both arguments, while they did not contradict the admonition to practice non-violence, reinforced inequitable gender stereotypes. The particular focus on prevention of male violence against women becomes justified by a sexist logic that emphasises women's supposed physical weakness, or that they are too useful a tool to damage. This logic undermines the broader aims of anti-violence against women campaigns and of women's equal rights to economic, social and political participation (Merry 2006). 
The second line of reasoning determined that violence was only illegitimate if it was unprovoked, excessive and the result of the perpetrator's lack of control or bad temper. In discussion about my research with Silas (an older man who was not a security guard), he noted how welcome it was that police had been doing more awareness raising about the laws related to violence against women in his area. 'You don't see as many women with black eyes and broken arms walking around', he said (discussion with Silas, North Coast Rabaul, 20 October 2012). He had observed that there was less legitimacy in village courts or in informal moots, such as ward counsel mediations, when men claimed that it was their 'right' to hit their wife because of a biblical principle of wifely submission, because they had paid bride price, or because she had pushed him to it; less pasin sori long ol man (overt bias favouring men). Silas saw that the law had become stronger, and people had to follow it in the name of development.

He had concerns about the law, however. Silas was unequivocal that it was good that bikhet or humbug man were more scared of legal consequences and being reported to the police or ward counsellor. They were more likely to think twice about hitting their wives because they had not prepared dinner on time, or they had got home late from work or from the market. However, he asked, what are families supposed to do, what should a husband do, if his wife is going around with other men? What if she is neglecting her children, and her duties, her garden and home to go dancing, drinking beer and sleeping around? If a man hits her to discipline her, then he's breaking the law. If he doesn't, she won't listen to what he says, and the family will break down. People will laugh at him and talk, they won't respect him in the community. What then?

As seen in the quote at the beginning of this section, where I asked the guards to translate the phrase 'a violent woman' into Tok Pisin, feminine violence was defined as behaviour that transgressed conservative imaginings of women's social place as much as outright aggression. 'Big head' women invite violence, push men out of control, and need to be taught lessons by men as the disciplinary heads of households (Banks 2000; Bradley 1992). In these accounts, the guards made distinctions between 'serious' attacks that a man bilong pait might enact, and 'just' a slap or a punch done to keep discipline in the household. By creating hierarchies of violence, men were able to minimise the seriousness of their own actions and mitigate their own culpability. As Mo Hume writes, the 'key to men's narratives was that they were not the worst [offenders]' (2009: 82). 
In talking about their own and friends' experiences of becoming frustrated and hitting women, the guards oscillated between expressing regret and blame. They were regretful that they did not know how else they could respond to egregious insults or insubordination from women in their households, especially wives and girlfriends, and still maintain pride and respect from peers and family. They experienced blame and anger towards the victim of violence for provoking the assault. Even the courts were complicit in reinforcing this line of thinking. A senior magistrate at Kokopo District Court had informed police officers working with the Family and Sexual Violence Unit (FSVU) that, contrary to National Directions Orders pertaining to Interim Protection Orders (IPOs), he would not be issuing the emergency restraining orders for domestic violence complaints on first hearings. One of the officers told me that the magistrate:

said that lots of women used to come into the court and get an IPO against their husband, where actually, they were in the wrong, they had provoked the situation that had come up and when their husband hit them, they ran to the police and said that it was all their husband's fault (interview with FSVU, Kokopo, April 2013).

Despite recognising that 'making the action' was illegal and wrong, underlying narratives of 'legitimate' male-on-male discipline in their recounting or reflections on domestic violence meant that acts of vindictiveness or rage could be reframed as disciplinary encounters, where women were 'taught a lesson' (Eves 2006). Equally troubling, this same logic was used to abdicate perpetrator responsibility for sexual assault, including gang rape, or lainups (Banks 2000; Hukula 2012; Lepani 2008). Such acts, acknowledged to be driven by mangal or selfish desire on the part of the man, were still said to be have been brought about by women being 'money-minded'. If they had not been out at night, or if they had been willing sex partners who had not requested money as compensation for sex, then they would not have been forced. Here too, men could use the complicity of legal institutions to blackmail women into sex, particularly if the perpetrator knew the victim's previous sexual partners.

If a friend of mine tells me that he's already slept with a woman, I will want to have sex with her too, it's a competition ... [if the woman doesn't want to] I'd force her, because I know the kind of woman she is, she just wants money or drinks. Or, I can threaten her with the law. If she doesn't go with me, then I'll take her to court, because she's already committed adultery (group discussion with Kokopo Security Guards, 3 October 2012). 
I argue that all of these acts exist on a continuum where both securitisation and discipline are invoked as explanations for punitive reactions against anyone suspected of causing 'social problems'. This allowed some men to manipulate discourses of securitisation to explain even the most vile acts of rape. Such explanations were not unproblematised by the men who weaved these narratives - punitive rape was not accepted as something that a 'good' man would do. However, for those that tried to rationalise acts of violence against women, the ability to be a good man was contingent on being in the company of good women. Women were positioned as the gatekeepers upholding community morality as well as being the catalyst for moral downfall. Rights-focused campaigns concentrate on gender equity from law and justice and from the health sector and seek to undermine the legitimacy and traction of these arguments. These have not been without success, including the unanimous passing of the Family Protection Act by National Parliament in 2013. However, they have not yet destabilised the element of aspirational masculinity, which holds that maintaining family discipline and upholding community discipline are part of being a good man (Howson 2014). The malleability of securitisation and discipline as a way of discursively framing acts of violence, and the paucity of responses from state and community authorities supposed to hold men accountable, mean that raskol acts were allowed to be reframed by men to fit with a raitman (upright, honorable man) ethos.

\section{Conclusion}

In this chapter, I have shown the continuum of how narratives of security and discipline are used to legitimate different forms of violence-from violence against criminals to rationalisations of rape. In doing so, I have explored the connections between historic legacies of male violence in many ethnic groups across Papua New Guinea and the narratives of violence today, the ways that brutal encounters with colonial 'pacification' have shaped attitudes to law and order (Jolly, Stewart with Brewer (eds) 2012), and the rupturing effect of multi-ethnic, neoliberal modernity and change on social selves and social controls in contemporary Papua New Guinea. To this mix, I also add development discourses-those that speak to a need to avoid state fragility and market-oriented definitions of 'insecurity', and those that seek to address violence against women by men as a distinct category of violence. The combined histories and continuing efforts to navigate precarity are used in various ways to excuse, 
explain and attempt to construct solutions. Inevitably, the approaches of different perspectives and actors within this milieu must be negotiated and reframed. All of these negotiations occur as part of existing power dynamics and struggles; all of them are, indelibly and critically, gendered. Hume reminds us that 'all research on violence is informed by silences ... restricting knowledge about violence and actively undermining efforts to challenge it'. Further:

as long as men and masculinities remain ignored in most analyses of violence, our knowledge remains limited, and normative understandings of violence that fail to uncritically unpack and problematize its masculinised dimensions are privileged (2009: 78).

My contention in this chapter is that ignoring the broader application of aggressive masculinity manifest in securitisation narratives, the benefits that such behaviours provide to bearers, and the harm violence causes men as well as women, limits the efficacy of interventions against violence.

\section{References}

Akmeemana, Sakuntala, Reno Diwa, Nicholas Menzies and Laura Bailey. 2014. Crimes and Disputes. Research and Dialogue Series. Washington: World Bank.

Alim, H. Samy. 2009. 'Straight outta Compton, straight aus München: Global linguistic flows, identities, and the politics of language in a global hip hop nation'. In Global Linguistic Flows: Hip Hop Cultures, Youth Identities, and the Politics of Language, ed. H. Samy Alim, Awad Ibrahim and Alastair Pennycook, pp. 1-24. New York: Routledge.

Amnesty International. 2006. Papua New Guinea: Violence Against Women: Not Inevitable, Never Acceptable. Port Moresby: Amnesty International.

Anderson, Stephanie. 2016. 'Manus Island detention centre to be shut, Papua New Guinea Prime Minister Peter O’Neill says'. ABC News, 27 April. Online: www.abc.net.au/news/2016-04-27/png-pm-oneill-toshut-manus-island-detention-centre/7364414 (accessed 26 June 2016). 
Banks, Cyndi. 2000. 'Contextualising sexual violence: Rape and carnal knowledge in Papua New Guinea'. In Reflections on Violence in Melanesia, ed. Sinclair Dinnen and Allison Ley, pp. 83-104. Leichhardt and Canberra: Hawkins Press and Asia Pacific Press.

-1993. Women in Transition: Social Control in Papua New Guinea. Canberra: Australian Institute of Criminology.

Bradley, Christine. 1992. Final Report on Domestic Violence 14. Port Moresby: Papua New Guinea Law Reform Commission.

Buur, Lars. 2008. 'Democracy and its discontents: Vigilantism, sovereignty and human rights in south Africa'. Review of African Political Economy 35(118): 571-84. doi.org/10.1080/03056240802569250.

Callinan, Rory. 2013. 'Australia funds lethal brute squad'. Age, 4 August. Online: www.theage.com.au/victoria/australia-funds-lethalbrute-squad-20130803-2r6g1.html (accessed 10 August 2014).

Consultative Implementation and Monitoring Council (CIMC) and Family and Sexual Violence Action Committee (FSVAC). n.d. Wife Beating is a Crime. Port Moresby: Family and Sexual Violence Action Committee.

Davey, Melissa. 2014. 'Manus security firm, G4S, responsible for February violence, says law centre'. Guardian, 23 September. Online: www.theguardian.com/world/2014/sep/23/manus-security-firm-g4sresponsible-for-february-violence-says-law-centre (accessed 15 April 2015).

Dinnen, Sinclair. 2001. Law and Order in a Weak State: Crime and Politics in Papua New Guinea. Honolulu: University of Hawai'i Press.

Dinnen, Sinclair and Abby Mcleod. 2008. 'The quest for integration: Australian approaches to security and development in the Pacific Islands'. Security Challenges 4(2): 23-43.

Eves, Richard. 2013. 'Sorcery and Witchcraft in Papua New Guinea: Problems in Definition'. State, Society and Governance in Melanesia, in brief 2013/12. Canberra: The Australian National University. 
2006. Exploring the Role of Men and Masculinities in Papua New Guinea in the 21st Century: How to Address Violence in Ways that Generate Empowerment for Both Men and Women. Report for Caritas Australia. Online: xyonline.net/sites/default/files/Eves,\%20Exploring\%20role\% 20of\%20men\%20PNG.pdf (accessed 17 November 2016).

Goldstein, Daniel M. 2010. 'Toward a critical anthropology of security'. Current Anthropology 51(4): 487-517. doi.org/10.1086/655393.

Independent State of Papua New Guinea. 2004. Security (Protection) Industry Act. Port Moresby.

Howson, Richard. 2014. 'Re-thinking aspiration and hegemonic masculinity in transnational context'. Masculinities and Social Change 3(1): 18-35.

Hukula, Fiona. 2012. 'Conversations with convicted rapists'. In Engendering Violence in Papua New Guinea, ed. Margaret Jolly, Christine Stewart with Carolyn Brewer, pp. 197-212. Canberra: ANU E Press. Online: press.anu.edu.au/publications/engenderingviolence-papua-new-guinea (accessed 23 August 2016).

Human Rights Watch. 2015. World Report 2015 Events of 2014. Human Rights Watch.

- 2005. Making Their Own Rules: Police Beatings, Rape, and Torture of Children in PNG. New York: Human Rights Watch.

Hume, Mo. 2009. 'Researching the gendered silences of violence in El Salvador'. IDS Bulletin 40(3): 78-85. doi.org/10.1111/j.17595436.2009.00042.x.

Jolly, Margaret, Christine Stewart with Carolyn Brewer (eds). 2012. Engendering Violence in Papua New Guinea. Canberra: ANU E Press. Online: press.anu.edu.au/publications/engendering-violence-papuanew-guinea (accessed 23 August 2016).

Klugman, Jeni, Lucia Hanmer, Sarah Twigg, Tazeen Hasan, Jennifer McCleary-Sills and Julieth Santamaria. 2014. Voice and Agency: Empowering Women and Girls for Shared Prosperity. Washington: World Bank. doi.org/10.1596/978-1-4648-0359-8. 
Lakhani, Sadaf and Alys M. Willman. 2014. Gates, Hired Guns and Mistrust: Business Unusual: The Cost of Crime and Violence to Businesses in PNG. Washington DC: World Bank Group.

Lepani, Katherine. 2008. 'Mobility, violence and the gendering of HIV in Papua New Guinea'. The Australian Journal of Anthropology 19(2): 150-64. doi.org/10.1111/j.1835-9310.2008.tb00119.x.

Macintyre, Martha. 2012. 'Gender violence in Melanesia and the problem of Millennium Development Goal No. 3'. In Engendering Violence in Papua New Guinea, ed. Margaret Jolly, Christine Stewart with Carolyn Brewer, pp. 239-66. Canberra: ANU E Press. Online: press.anu.edu.au/publications/engendering-violence-papua-newguinea (accessed 23 August 2016).

- 2008. 'Police and thieves, gunmen and drunks: Problems with men and problems with society in Papua New Guinea'. The Australian Journal of Anthropology 19(2): 179-93. doi.org/10.1111/j.1835-9310.2008. tb00121.x.

Martin, Keir. 2013. The Death of the Big Men and the Rise of the Big Shots: Custom and Conflict in East New Britain. New York and Oxford: Berghan Books.

Mcleod, Abby and Martha Macintyre. 2010. 'The Royal Papua New Guinea constabulary'. In Civic Insecurity: Law, Order and HIV in Papua New Guinea, ed. Vicki Luker and Sinclair Dinnen, pp. 167-78. Canberra: ANU E Press. Online: press.anu.edu.au/ publications/series/state-society-and-governance-melanesia/civicinsecurity (accessed 23 August 2016).

McVeigh, Karen. 2015. 'Canada mining firm compensates Papua New Guinea woman after alleged rapes'. Guardian Online, 4 April. Online: www.theguardian.com/world/2015/apr/03/canada-barrickgold-mining-compensates-papua-new-guinea-women-rape (accessed 15 April 2015).

Merry, Sally Engle. 2006. Human Rights and Gender Violence: Translating International Law into Local Justice. Chicago: University of Chicago Press. 
Mitchell, Jean. 2000. 'Violence as continuity: violence as rupturenarratives from an urban settlement in Vanuatu'. In Reflections on Violence in Melanesia, ed. Sinclair Dinnen and Allison Ley, pp. 189208. Leichhardt and Canberra: Hawkins Press and Asia Pacific Press.

O'Connor, Tim, Sharni Chan and James Goodman. 2006. 'Australian aid: Promoting insecurity?' In The Reality of Aid Report 2006, ed. The Reality of Aid, pp. 175-89. Quezon City: The Reality of Aid.

Pacific Economic Monitor. 2014. 'Papua New Guinea Economic and Labor Market Update'. July 2014. In Economic Update. Philippines: Asian Development Bank.

Papua New Guinea-Australia Law and Justice Partnership. 2013. 'Fact Sheet 9: Royal Papua New Guinea Constabulary (RPNGC)'. Canberra: Papua New Guinea-Australia Law and Justice Partnership.

PNG Ports Corporation. 2013. 'PNGPCL support "Haus Krai" on gender violence,' 21 May. Online: www.pngports.com.pg/index. php/latest-news/1233-pngpcl-support-haus-krai-on-gender-violence (accessed 20 April 2015).

Scott, Ben. 2005. Re-imagining PNG: Culture, Democracy and Australia's Role. Lowy Institute Paper No. 09. Double Bay: Lowy Institute for International Policy.

Security Industries Authority (SIA). 2014. 'Current status of the security business in PNG,' Security Companies Information. Security Industries Authority. Online: sia.gov.pg/seccomps.html (accessed 20 August 2014).

Stewart, Christine. 2014. Name, Shame and Blame: Criminalising Consensual Sex in Papua New Guinea. Canberra: ANU Press. Online: press.anu.edu. au/publications/name-shame-and-blame (accessed 23 August 2016).

Wardlow, Holly. 2011. 'The task of the HIV translator: Transforming global AIDS knowledge in an awareness workshop'. Medical Anthropology: Cross-Cultural Studies in Health and Illness 31(5): 404-19. doi.org/10. 1080/01459740.2012.661002.

Wolfe, Asher. 2014. 'Manus Island guards unlicensed, says PNG regulator'. SBS News Australia, 17 March. Online: www.sbs.com.au/ news/article/2014/03/17/manus-island-guards-unlicensed-says-pngregulator (accessed 10 August 2014). 
This text is taken from Transformations of Gender in Melanesia, edited by Martha Macintyre and Ceridwen Spark, published 2017 by ANU Press, The Australian National University, Canberra, Australia. 